\title{
Julkisen hallinnon haasteita ja mahdollisuuksia digitaalisessa transformaatiossa
}

\author{
Riikka Palomäki
}

\section{ABSTRACT \\ Challenges and opportunities for public administration in digital transformation}

This article focuses on challenges and wicked problems that public administration faces in digitalisation and digital transformation, and outlines ways to overcome these issues. Digitalisation will increase in all areas of our society in the coming years, and will affect the delivery of public administration and public governance. The complex nature of public administration, the lack of continuity due to the political decision-making system, the legislative focus and the pace and the nature of digitalisation seem to be the biggest challenges or even wicked problems of public administration in advancing and implementing the digital transformation. The realization of digital transformation in public administration requires better understanding of digitalisation as a phenomenom, the creation of an agile, soft, strategy and a clear goal for digitalisation, not forgetting the importance of leadership. Digital transformation in public administration also requires acceptance and utilization of the complexity of public administration, not its denial or disregard.

Keywords: public administration, digitalisation, digital transformation, wicked problem, strategy, leadership

\section{JOHDANTO}

Digitalisaation, automatisaation ja muun teknologisen kehityksen on pitkään ennustettu vähentävän suorittavan työn määrää ja lisäävän asiantuntijatason työtä ja erikoisosaajien tarvetta or- ganisaatioissa ja yrityksissä (Työ- ja elinkeinoministeriö 2017, 17-18; Työ- ja elinkeinoministeriö 2019, 95-97). Työn murros koskettaa myös johtamista; digitalisaatio muokkaa johtamisen käytäntöjä ja sisältöä, ja monet johtamiseen liittyvät funktiot ovat korvattavissa ja osin jo korvattu digitaalisilla ratkaisuilla (Larjovuori, Bordi, Mäkiniemi \& Heikkilä-Tammi 2016, 1141-1142; Hesse 2018, 1858-1859). Kun digitalisaatio ja digivallankumous toteutuu, on julkisen hallinnon ja johtamisen mukauduttava ja muokkauduttava voidakseen vastata uudenlaisiin ja yhä kompleksisimpiin hyvinvointi-, palvelu-, ja toiminnallisiin tarpeisiin ja kyettävä löytämään ratkaisuja digitalisaatioon liittyviin mahdollisiin, jopa todennäköisiin, pirullisiin ongelmiin (wicked problems) (Holtel 2016, 171-172; Nyholm, Airaksinen \& Haveri 2016, 231; Valtiovarainministeriö 2019a, 10).

Tarve muuttua ja uudistua ei ole julkisessa hallinnossa ja julkisessa johtamisessa uusi haaste, mutta nyt haasteelliseksi sen tekee juuri muutosvoimakkuuden ja -nopeuden ennustettu kasvu ja laajuus (Sydänmaanlakka 2015, 26-27). Digitalisaatio on ilmiönä haastava ja monitahoinen. Viime aikoina on noussut keskusteluun myös hyvin skeptisiä näkemyksiä digitalisaation ja siihen sisältyvän digitaalisen teknologian integraation hyödyntämisen (digitaalinen transformaatio) etenemisestä ja merkityksestä julkisessa hallinnossa ja johtamisessa. Tässä artikkelissa tarkastellaan julkisen hallinnon haasteita ja mahdollisuuksia digitaalisen transformaation läpiviemisessä sekä pohditaan, miten digitalisaatioon ja erityisesti digitaaliseen transformaatioon liittyviä haasteita voitaisiin hallita. Artikkelin tarkoituksena on pohtia, 1) millaisia haasteita ja jopa pirullisiksi muodostuvia ongelmia digitaalinen transformaatio aikaansaa julkisissa organi- 
saatioissa, ja 2) miten nämä haasteet ja ongelmat voitaisiin ratkaista, jotta digitaalinen transformaatio toteutuisi hallitusti.

\section{DIGITALISAATIO ILMIÖNÄ JA OSANA ORGANISAATIOTA}

\section{Digitalisaation määrittelyjä}

Digitalisaation ja digitaalisen vallankumouksen käynnisti ohjelmoitavien logiikkojen, robottien, tietokoneiden ja automatisaation käyttöönotto 1960-luvulla (Drath \& Horch 2014, 56-57). Digitalisaation, tekoälyn, ja muun teknologisen kehityksen lähitulevaisuuttakin on hyvin haasteellista ennustaa digitalisaation kehittymisen eksponentiaalisuuden vuoksi (Alasoini 2015, 28). Ennuste teknologisen kehityksen ja digitalisaation kasvun eksponentiaalisuudesta pohjautuu Gordon E. Mooren (1965) esittämään Mooren lakiin, jonka mukaan mikropiirien transistoreiden lukumäärä (eli tietokoneiden tietojenkäsittelykapasiteetti) tuplaantuu joka toinen vuosi (Ilmarinen \& Koskela 2015, 27). Tulevaisuudentutkija Martin Ford on kuvannut teknologisen kehityksen kiihtymistä kuvaavasti dramaattiseksi, ja toteaa, että käynnissä oleva nopea ja vaikeasti ennustettava murros näkyy tietokoneiden laskentatehon eksponentiaalista kasvua kuvaavan Mooren lain mukaisesti teknologisessa kehityksessä laajemminkin vaikuttaen myös esimerkiksi työmarkkinoiden ja talouden kehittymiseen, jokapäiväistä arkeamme unohtamatta (Ford 2015, 9-17).

Digitalisaatio on ilmiönä monisyinen, kompleksinen ja nopeasti muuttuva, mikä ilmenee digitalisaatioilmiön lukemattomina erilaisina määritelminä ja selityksinä tieteellisissä julkaisuissa ja medioissa. Teknisestä näkökulmasta digitalisaatio tarkoittaa esimerkiksi Siukosen ja Neittaanmäen $(2019,52)$ mukaan: "tietokoneiden koodattua informaatiota, jonka käsittelyyn tarvitaan digitaalisia prosessoreita, muistia ja siirtoteknologiaa." Business Dictionaryn mukaan digitalisaatio on: "Digitaalisten teknologioiden yhdistämistä kiinteäksi osaksi ihmisten jokapäiväistä elämää”. Alasoini $(2015,26)$, Kenney , Rouvinen ja Zysman $(2015,1)$ sekä Hämäläinen, Maula \& Suominen $(2016,21)$ tulkitsevat digitalisaatiota samansuuntaisesti, ja näkevät sen merkitsevän muutakin kuin yksittäisen organi- saation muuttumista digitaaliseksi tai digitaalisten toimintojen käyttöönottoa organisaatiossa; digitalisaatio on merkitykseltään teolliseen vallankumoukseen verrattava laaja ja monitahoinen yhteiskunnallinen ilmiö, jossa koko toimintaympäristö muuttuu digitekniikan ja uusien teknologisten innovaatioiden myötä.

Digitalisaation ohella käytetään myös termiä digitaalinen transformaatio, jolla tarkoitetaan digitaalisen teknologian hyödyntämistä ja integraatiota kaikkiin elämän osa-alueisiin. Digitaalisesta transformaatiosta seuraa ihmisten käyttäytymisen, markkinoiden dynamiikan ja yritysten ydintoiminnan radikaali muuttuminen (Collin 2015, 29; Ilmarinen \& Koskela 2015, 21-22; 239-240; Bilefield 2016; Gartner 2018.) Kyseessä on organisaatioita, niiden johtamista, kulttuuria ja toimintaympäristöä kokonaisvaltaisesti muokkaavana ja jatkuvasti kehittyvänä prosessi, jonka myötä syntyy uudenlainen suhde ihmisen ja koneen välillä. (Larjovuori ym. 2016, 1141; Hesse 2018, 1854; Työ- ja elinkeinoministeriö 2018, 13).

Digitalisaatioon liittyvissä muutoksissa on yleisesti mukana tekoäly, ja sen ja muun digitalisaation vaikutuksia on vaikea erottaa toisistaan (Työ- ja elinkeinoministeriö 2018, 10). Tekoälyn avulla digitalisaation ja teknologisen kehityksen mahdollistamat muutokset saadaan automatisoitua tai ylipäätään toteutettua, joten tekoälyn voidaan sanoa olevan osa modernia digitalisaatiota hyödyntävää palveluyhteiskuntaa (Siukonen \& Neittaanmäki 2019, 11). Uusien teknologisten ratkaisujen myötä tekoälyn käsite laajenee ja muuttuu yhä monisyisemmäksi. Tekoälytutkijat Russel ja Norvig $(2003,1-5)$ ovat määritelleet tekoälyä sen toiminnallisten ominaisuuksien kautta; tekoäly aikaansaa sen, että koneet, laitteet, järjestelmät ja palvelut osaavat erilaisissa konteksteissa toimia, oppia, päätellä ja ennakoida älykkäältä vaikuttavalla tavalla.

\section{Digitaalista transformaatiota kohti kulkevan organisaation strategia ja dynaamiset kyvykkyydet}

Organisaatioiden kyky kohdata muutoksia ja vastata niistä aiheutuneisiin kehitys- ja uudistumisvaatimistarpeisiin riippuu organisaation dynaamisista kyvykkyyksistä (Eisenhardt \& Martin 2000, 1106-1107; Teece, Pisano \& Shuen 1997, 
516; Teece 2018, 43-44). Erityisesti nopeasti muuttuvilla toimialoilla ja hyvin merkittävän muutostilanteen yhteydessä, kuten digitaalisen transformaation, ovat dynaamiset kyvykkyydet ratkaisevassa roolissa. Ne näkyvät siinä, miten organisaatio kykenee arvioimaan, ennakoimaan ja järjestämään osaamistaan, resurssejaan ja toimintojaan vastaamaan tarpeitaan sekä luomaan kilpailuetua (Eisenhardt \& Martin 2000, 11061107; Teece ym. 1997, 516; Teece 2018, 43-44). Vaikka dynaamiset kyvykkyydet mielletäänkin enemmän liiketoiminnan kehittämiseen kuuluviksi kilpailuedun luojiksi, voi niitä tarkastella myös julkisen sektorin näkökulmasta. Dynaamisten kyvykkyyksien sisältö on suurelta osin sama, mutta motiivit siihen eivät kaikin osin ole kilpailuedun ollessa poissa kuvasta. Julkisella sektorilla organisaation dynaaminen kyvykkyys on strategista kykyä sopeuttaa organisaation palvelutoimintaa ja palvelujen tuotantoa muuttuvissa olosuhteissa (Pablo, Reay, Dewald \& Casebeer 2007, 691-692).

Julkisen organisaation dynaaminen kyvykkyys ilmenee juuri strategiaprosessien kautta. Julkisen hallinnon keinona toimintaympäristön muutosten ja epävarmuuden hallinnassa on perinteisesti ollut strategisen suunnittelu ja tulevaisuuteen suuntautuvien strategioiden laatiminen (Sotarauta 1996, 10, 14). Digitalisaation etenemistä kuvaavien "digikypsyyden mallien" (digital maturity model) (esim. Gartner 2017) perusteella digitalisaatiossa menestymisen keskeisemmät osa-alueet liittyvät organisaation strategiaan ja organisaatiokulttuuriin. Digitaalisesti kypsissä organisaatioissa on selkeä, kokonaisvaltainen ja koherentti digistrategia, jonka avulla digitalisaatio siirtyy organisaation kokonaisprosesseihin, toimintakäytäntöihin ja liiketoimintamalleihin (Berman 2012, 16; Kane, Palmer, Phillips, Kiron \& Buckley 2015; Larjovuori ym. 2016, 1143 1144). Digitalisaation nopeuden ja kompleksisuuden vuoksi perinteinen, pitkän aikavälin suunnitteluun ja vakaaseen toimintaympäristöön perustuva strategiatyö ei ole enää toimivaa. Organisaatiot voivat strategisessa suunnittelussaan käyttää hyväksi tulevaisuuden ja toiminnan epävarmuutta, moniulotteisuutta ja lyhytjänteisyyttä (Sotarauta 1996, 12, 14, 33; Teece 2018, 43-44). Digitaalisessa transformaatiossa onnistuvat organisaatiot kykenevät nopeampaan, kokeilevampaan ja samalla osallistavam- paan strategian luomiseen, jossa myös hallittu riskien ottaminen ja epäonnistumisen mahdollisuus hyväksytään (Kane 2015; Hämäläinen ym. 2016, 15-17, 67).

Digitaalinen transformaatio edellyttää huomion kiinnittämistä myös organisaation kulttuuriin. Maula (2016) tuo hyvin esiin, että strategian muutos ja uudistuminen ei onnistu ilman organisaatiokulttuurin muuttumista. Dynaamisesti kyvykkäissä organisaatioissa johto ja eri tasojen esimiehet ovat avainasemassa organisaation strategisten tavoitteiden ja muutosten eteenpäin viejinä, luoden kaikkia organisaation toimijoita osallistavaa ja avointa toiminta- ja organisaatiokulttuuria. Avoin, kokeileva ja riskejä sietävä organisaatiokulttuuri lisää dynaamista kyvykkyyttä tehden samalla organisaatiosta ketterän ja reagointikykyisen. (Kane ym. 2015; Larjovuori ym. 2016: 1143-1144; Pablo ym. 2007, 703-706.)

\section{DIGITALISAALISEN TRANSFORMAATION TARKASTELUA JOHTAMISTEOREETTISESTA NÄKÖKULMASTA}

Digitalisaation etenemistä julkisella sektorilla voi analysoida tarkastelemalla julkisen hallinnon julkista luonnetta ja sen taustalla vaikuttavia johtamisen teorioita. Julkisen hallinnon teoriat voidaan Osbornen (2006, 377-381) mukaan jaotella perinteiseen julkiseen hallintoon ja johtamiseen, uuteen julkiseen johtamiseen (New Public Management; NPM) ja julkiseen hallintaan (New Public Governance). Teoriat kuvaavat voimassa olevaa hallintoideologiaa, hallitusfunktioiden järjestämisen lähtökohtana olevaa institutionaalista logiikkaa, eli periaatteita, jotka ohjaavat toimijoiden, tässä tapauksessa julkisen hallinnon ja julkisen johtamisen toimintaa, ajattelua ja käyttäytymistä (Stenvall, af Ursin, Tiihonen, Nyholm \& Airaksinen 2016: 33). Tästä viitekehyksestä tarkasteltuna voidaan päätellä julkisessa hallinnossa siirrytyn perinteisestä weberiläisestä byrokraattisesta, ideaalisesti demokraattiseen poliittiseen päätöksentekoon perustuvasta hallinnosta aikaansaannoksia ja tehokkuutta painottavaan uuteen julkiseen johtamiseen ja edelleen kohti verkostomaista ja kerrostunutta julkisen hallinnan mallia (Sydänmaanlakka 2015, 57; Osborne 2006, 377-382; Stenvall ym. 2016, 35; Virtanen \& Stenvall 2019, 36-37). 
Julkisen hallinnan malliin sisältyy näkemys hallinnon kompleksisuudesta: organisaatiot nähdään jatkuvasti kehittyvinä ajallisina, fyysisinä ja psyykkisinä tiloina ja hybridimaisina verkostoina, jotka elävät monimuotoisissa, monitulkintaisissa ja muuttuvissa toimintaympäristöissä (Osborne 2006, 382-384; Virtanen \& Stenvall 2014, 19; Sydänmaanlakka 2015, 29-32). Siinä missä uusi julkinen johtaminen tähtäsi julkisien organisaatioiden uudistamiseen ja tehostamiseen siilomaisia byrokraattisia rakenteita muuttamalla ja julkisen ja yksityisen sektorin rajaa murtamalla, korostuu julkisessa hallinnassa verkostoituminen, monitoimijaiset systeemit sekä hallinnan ja johtamisen prosessien kehittäminen rakenteiden sijaan (Nordin \& Parviainen 2018, 37-38; Osborne 2006, 379-382; Stenvall ym. 2016, 56).

Näkemys asiakkaasta ja asiakkaan asemasta on muuttunut johtamismallien muutoksen myötä. Perinteisen julkisen hallinnon aikana asiakas nähtiin pelkästään passiivisena palveluiden kohteena tai vastaanottajana, uuden julkisen johtamisen aikakautena puolestaan asiakkaasta tuli kuluttaja, palveluiden käyttäjä ja rahoittaja, jolla oli myös oikeuksia vaatia vastinetta rahoilleen. Julkisen hallinnan mallissa asiakas on olennaisesti mukana palveluiden tuottamisessa ja kehittämisessä, ja siinä korostuu asiakaslähtöisyys ja asiakaskeskeisyys. (Virtanen \& Stenvall 2019, 54-56.) Sekä Stenvall, Laitinen, af Ursin, Virtanen \& Kaivo-oja $(2014,23)$ että Katarina L Gidlund $(2015,222,224)$ näkevät teknologisen kehityksen mahdollistavan asiakkaan aktiivisen osallistumisen palveluiden kehittämiseen. Westerman, Bonnet ja McAfee (2014, 34-35, 45) puolestaan korostavat asiakastiedon ja asiakkaiden osallistamisen merkitystä organisaation digitalisaation onnistumisessa. Digitalisaation voidaan nähdä tukevan julkisen hallinnan näkemystä asiakkaasta aktiivisena, osallistuvana ja tasavertaisena toimijana. Julkisen hallinnon digitalisaatiohankkeet kohdistuvatkin usein uudenlaisten palvelumuotojen ja -kanavien kehittämiseen asiakaslähtöisesti (Larjovuori ym. 2016, 1141; Valtiovarainministeriö 2017a, 1417; Valtiovarainministeriö 2019a, 10-11; Valtiovarainministeriö 2019b).

Vaikka julkisen johtamisen teoriat voidaan asettaakin ajallisesti toisiaan seuraaviksi, eivät ne käytännössä ole toisiaan poissulkevia; julki- sessa hallinnossa voidaan nähdä aina piirteitä aiemmista vallalla olevista malleista (Sydänmaanlakka 2015, 57; Stenvall ym. 2016, 35). Eri mallien kerroksittaisuus johtaa tilanteeseen, missä julkisessa hallinnossa tasapainoillaan edelleen perinteisen, muodollisen ja ylhäältä alas toteutettavan byrokraattisen hallinnon, tuloksellisuutta, tulosohjausta ja yksityiseltä sektorilta omaksuttujen periaatteiden toteuttamista painottavan uuden julkisen johtamisen sekä adaptiivisuutta, dynaamisuutta ja verkostomaisuutta tavoittelevan julkisen hallinnan välillä (Ikonen 2015, 25, 35, 40-41; Murphy, Meek, Rhodes \& Denyer 2017, 692).

Vaikka julkisessa hallinnossa korostetaan nykyisin digitalisuuteenkin kuuluvia ominaisuuksia; verkostomaisuutta, joustavuutta ja ketteryyttä, vaikuttaa taustalla vahvasti edelleen byrokraattiseen perinteiseen johtamiseen kuuluvat yhdenvertaisuuden, valvonnan ja oikeudenmukaisuuden periaatteet sekä voimakas ohjaukseen ja valvontaan perustuva toimintakulttuuri (Nordin \& Parviainen 2018, 41; Stenvall ym. 2016, 57-58; Virtanen \& Stenvall 2019, 39-40). Julkisen hallinnon kompleksisuutta lisää myös hallinnossa vaikuttavat erilaiset valtasuhteet ja useat toimijat kuten viranomaiset, poliittinen päätöksenteko, lainsäädäntö ja julkisten palvelujen asiakkaat, ja julkisen hallinnon tehtävät ja rooli ankkuroituvat yhteiskuntapoliittisesti koko talouselämää koskeviin ideologisiin lähtökohtiin (Laitinen, Stenvall, Nyholm \& Kaivo-oja 2015, 9, 55; Valkama \& Anttiroiko 2011, 260). Nämä sinänsä hyvät suomalaiseenkin hallintojärjestelmään kuuluvat periaatteet ja perusrakenteet saattavat tehdä julkisesta hallinnosta ja sen toiminnan uudistamisesta jäykkää, pirstaleista ja tehotonta.

Julkista hallintoa ohjataan vahvasti perinteisestä julkisesta johtamisesta juontuvalla lainsäädännöllä, jonka avulla pyritään vastaamaan yhteiskunnallisiin tavoitteisiin ja julkisten palveluiden käyttäjien tarpeisiin (Ikonen 2015, 82; Virtanen \& Stenvall 2014, 48-54; Pekkola, Haveri \& af Ursin 2016, 21). Lainsäädäntökeskeisyyden vuoksi digitalisaation edellyttämien ja sitä edistävien hallinnollisten prosessien muuttaminen on kankeaa ja hidasta sekä usein yksittäisestä organisaatiosta lähtevää toimintaa, jossa digitalisaatioon olennaisesti kuuluva ketteryys saattaa jäädä huomioimatta (Ikonen 2015, 44-45). 
Lainsäädännössä ei myöskään kyetä huomioimaan tai tukemaan riittävän joustavasti ja nopeasti poikkihallinnollisia toimintoja eikä yhtenäisiä käytäntöjä, joita tarvittaisiin esimerkiksi eri viranomaisten välisen yhteistyön lisäämiseksi ja yhtenäisen digitaalisen tietopohjan luomiseksi (Gartner 2017; Valtiovarainministeriö 2017a, 21-22; Valtiovarainministeriö 2017b, 17-18).

Esimerkiksi perustuslakiin kirjattu yhdenvertaisuuden periaate on toisaalta "suoja", jolla turvataan perinteisten palvelumuotojen säilyminen niitä tarvitseville asiakkaille tai organisaatioille, mutta samalla se voi estää innovatiivisten digitaalisten ratkaisujen kehittämisen esimerkiksi julkisen ja yksityisen tai kolmannen sektorin välillä. Tämä on nähtävissä käytännössä esimerkiksi 1.4.2019 voimaan tulleessa digitaalisten palvelujen tarjoamista koskevassa laissa, jonka mukaan viranomaisten on järjestettävä turvalliset ja laadukkaat digitaaliset palvelut, mutta samalla laissa todetaan, että kansalaisia ei voida pakottaa vain digitaalisten palvelujen käyttöön (Laki digitaalisten palvelujen tarjoamisesta 306/2019).

Julkisen hallinnon julkinen luonne tuo mukanaan poliittisen aspektin, mikä saa aikaan julkisen hallinnon digitalisaatiossa jatkuvuuden puutteen. Politiikan ja julkisen hallinnon suhde on kompleksinen, vaikka poliittista päätöksentekoa ja julkista valtaa on pyritty esimerkiksi jo uuden julkisen johtamisen myötä erottamaan toisistaan. Samoin myös julkisen hallinnan mallissa korostuu vuorovaikutteinen, yhteistyölähtöinen ja hajautettu julkisen politiikan toteuttaminen. (Virtanen \& Stenvall 2019, 42-43; 46-47.)

Poliittisen päätöksentekojärjestelmän syklimäisyys tuo haasteen digitalisaation kaltaisen ilmiön etenemiseen: hallitusten vaihtuessa prioriteetit saattavat muuttua ja jo käynnistyneet hankkeet keskeytyä, eikä pidempiaikaista kehitystä, rahoitusta tai vastuutahoa kyetä määrittämään (Gartner 2017). Sekä Sipilän hallituksen että Marinin hallituksen ohjelmissa digitalisaatio tosin näyttäytyy molemmissa läpileikkaavana teemana; Sipilän hallitusohjelmassa yhtenä kärkihankkeena ja Marinin hallitusohjelmassa $\mathrm{mm}$. tavoitteena rakentaa digitalisaation edistämisen ohjelma julkisten palveluiden digitalisoimiseksi (Valtiovarainministeriö 2019b, 12, 28; Valtiovarainministeriö 2020, 3-4).
Toinen poliittiseen päätöksentekojärjestelmään liittyvä ongelma on pyrkimys laajaan konsensukseen. Vaikka jo uuden julkisen johtamisen myötä on alettu tavoitella enemmän joustavuutta, tehokkuutta ja itseohjautuvuutta, on suomalaiselle politiikalle ja julkiselle hallinnolle edelleen luontaista konsensushakuisuus, mikä tuo myös haasteen digitalisaatiolle. Haettaessa uudenlaisia tapoja toimia, on vaarana ajautua kaavamaiseen, yksiääniseen ja pirstaleiseen uudistamiseen, mikäli ei kyetä luopumaan yksimielisyyden ja yhdenmukaisuuden tavoitteista. (Haveri \& Airaksinen 2012, 312-313; Ikonen 2015, 45-47; Lähdesmäki 2011, 82-84.)

Digitalisaatio ja teknologinen kehitys näyttävät kulkevan käsi kädessä julkisen hallinnon mallien kehittymisen kanssa. Esimerkiksi julkisen hallinnan mallin ideaalinen ilmeneminen tavallaan edellyttää myös digitalisaation toteutumista, mutta saman voi nähdä myös toisin päin: digitaalinen murros mahdollistaa julkisen hallinnan mallin toteuttamisen. Julkisen hallinnon mallien nykyisenkaltainen kerroksisuus ja erilaiset hallinnon taustalla vaikuttavat tekijät tekevät digitalisaation etenemisestä haasteellista, vaikkakin etenkin julkisen hallinnan malli esimerkiksi prosessien uudistamiseen ja kokonaisvaltaisuuteen painottuen tukee digitaalisia ilmiöitä ja digitaalisen transformaation toteutumista. Julkisen hallinnon digitalisoitumista ilmentää kuitenkin edelleen uudesta julkisesta johtamisesta juontava jo olemassa olevista rakenteista lähtevä uudistaminen; esimerkiksi uuden teknologian soveltaminen suoraan olemassa oleviin palveluihin ja digitaalisten ratkaisujen etsiminen organisaatiokeskeisesti tai suoraan yksityiseltä sektorilta kopioimalla. Kun tähän lisätään taustalla edelleen vahvasti vaikuttava byrokraattinen ohjaus- ja valvontajärjestelmä, on riskinä, että digitalisaation etenemisestä tulee pirstaleista, hidasta ja ennakoimatonta. Herää kysymys, mikä on teknologisen kehityksen todellinen rooli ja vaikutus julkisen hallinnon mallien sisältöön ja niiden kautta julkisen hallinnon toimintaan ja ilmenemiseen. Ohjaako teknologinen kehitys sitä, millaiseksi eri aikana julkinen hallinto ja sen sisältö muotoutuvat, ja onko teknologisella kehityksellä jopa liian suuri rooli siinä, mikä milloinkin nähdään tarkoituksenmukaisena ja tavoiteltavana julkisena toimintana. 


\section{DIGITALISAATIO JULKISESSA HALLINNOSSA; TODELLISUUTTA VAI VASTA TAHTOTILA?}

Digitalisaatio nähdään Suomessa julkisen hallinnonkin tulevaisuutta koskevissa keskusteluissa koko julkista sektoria mullistavana asiana. Digitalisaation edetessä rajan julkisen hallinnon, yksityisten toimijoiden ja kolmannen sektorin välillä uskotaan hämärtyvän, ja samalla erilainen poikkihallinnollinen yhteistoiminta sekä riippuvuudet toimijatahojen välillä lisääntyvät muodostaen lopulta integroidun ja monimuotoisen alustamaisen kokonaisuuden (Valtiovarainministeriö 2017a, 14-16; Valtioneuvosto 2019a, 29-33). Vuonna 2017 käynnistetyn Tekoälyohjelman tavoitteeksi asetettiin Suomen johdattaminen tekoälyä soveltavien maiden kärkijoukkoon (Työ- ja elinkeinoministeriö 2019, 9). Lisäksi Sipilän hallituksen Digitalisoidaan julkiset palvelut-kärkihankkeen johdosta on mm. vahvistettu julkisia palveluja koskevat digitalisoinnin periaatteet, edistetty digitaalisten palveluiden kehittämistä ja yhtenäisyyttä julkisella sektorilla sekä perustettu erilaisia työryhmiä ja hankkeita aiheen ympärille (Valtiovarainministeriö 2019b, 12, 28).

Digitalisaation edistymistä on tuettu myös lainsäädännöllä; 1.4.2019 voimaan astui laki digitaalisten palveluiden tarjoamisesta ja 1.1.2020 astui voimaan uusi julkisen hallinnon tiedonhallintalaki (Laki digitaalisten palvelujen tarjoamisesta 306/2019; Laki julkisen hallinnon tiedonhallinnasta 906/2019). Digitaalisuuden ja teknologisen kehityksen hyödyntämisen tavoite näkyy Suomessa myös julkisten organisaatioiden strategioissa ja visioissa laajalti. Organisaatiotasolla esimerkiksi Verohallinnossa, poliisissa ja Kelalla strategioissa nostetaan esiin tekoälyn ja digitalisaation hyödyntämisen kehittäminen organisaation palveluissa, prosesseissa ja toiminnassa (Poliisi 2017; Kela 2019; Verohallinto 2019a).

Tekoälyn, teknologisen kehityksen, automatisaation ja robotiikan myötä on ennustettu tapahtuvan muutoksia julkisen sektorin työtehtävissä, työn sisällössä, palvelujen ja toimintojen toteuttamisessa sekä näiden ohella myös julkisessa johtamisessa ja sen valtarakenteissa (Ailisto, Neuvonen, Nyman, Halén \& Seppälä 2019, 4; Valtiovarainministeriö 2017b, 84-85). Teknologisen kehityksen on nähty mahdollis- tavan laajempia julkisen toiminnan kehittämismahdollisuuksia ennakointikykyisempään, verkostomaiseen ja horisontaaliseen suuntaan, tuovan kustannussäästöjä ja avaavan uudenlaisia asiakaslähtöisempiä palvelutransformaatioita (Valtiovarainministeriö 2017a, 11-15; Valtiovarainministeriö 2017b, 84-85). Yhtenä esimerkkinä digitalisaation hyödyntämisestä julkisessa hallinnossa on edellisellä hallituskaudella aloitettu valtiovarainministeriön koordinoima Aurora AI-ohjelma. Aurora AI:n tavoitteena on vauhdittaa julkisen hallinnon siirtymistä digiaikaan, ja luoda tekoälyn ja autonomisten sovellusten muodostama organisaatioiden verkko, joka mahdollistaa monien eri palveluntuottajien palveluista koostuvat saumattomat ja sujuvat palvelupolut. (Valtiovarainministeriö 2019a, 8, 16-17; Valtiovarainministeriö 2019b, 29.)

Julkisen hallinnon luonteen vuoksi uusiin digitalisaation mahdollistamiin innovaatioihin sisältyy erilaisia vastuuseen ja luotettavuuteen liittyviä odotuksia ja kysymyksiä. Digitaalisten ratkaisujen edellytetään ainakin toistaiseksi olevan vain vaihtoehtona perinteisille palveluille ja toiminnoille, mikä johtaa päällekkäisiin toimintamalleihin ja pahimmillaan jopa päällekkäiseen työhön. Digipalvelulakiin on kirjattu edellytys palveluiden turvallisuudesta ja laadukkuudesta, minkä vuoksi digitaalisia palveluita kehitettäessä ja otettaessa käyttöön halutaan välttää riskejä palveluiden toimimattomuudesta ja epäonnistumisesta. Näiden riskien toteutuminen voi johtaa esimerkiksi palvelujen kaatumiseen, asiakasta koskeviin virheisiin tai tietosuojaongelmiin. Julkisuuteen on jo tullut toteutuneitakin riskejä; viimeisimpänä Verohallinnon virheelliset kirjeet ja päätökset (Verohallinto 2019b). Tasapainoilu innovatiivisen kehittämisen ja luotettavuuden välillä on julkiselle hallinnolle haaste.

Vaikka digitalisaatio on voimakkaasti esillä julkisen hallinnon uudistamista koskevassa keskustelussa, näyttäytyy julkisen hallinnon toiminnan todellisuus digitalisaation suhteen kompleksisena. Vaikka julkisessa hallinnossa tämänhetkistä digitalisaation etenemistä kuvataan digitaalisena transformaationa, on myös herännyt yhä enemmän kriittistä keskustelua siitä, millaisesta muutoksesta voidaan tässä vaiheessa puhua. Esimerkiksi Sorin Dan (2019) tuo esiin digitaalisen transformaation olevan paljon enemmän kuin muutoksia yksittäisten organi- 
saatioiden toiminnassa tai niiden käyttämissä teknologisissa ratkaisuissa. Digitaalinen transformaatio merkitsee Danin mukaan radikaalia murrosta, jollaista ei hänen mukaansa ole vielä nähtävissä julkisessa hallinnossa. Viitaten aiemmin esiin nostettuihin dynaamisiin kyvykkyyksiin näyttääkin siltä, että julkisessa hallinnossa ei olla vielä riittävästi tiedostettu millaisella osaamisella, toiminnalla ja strategisella suunnittelulla digitaalisessa transformaatiossa voitaisiin edetä.

Digitalisaation mahdollistamien muutosten ja niiden vaikutusten täydellinen ennakointi on mahdotonta, ja tulevaisuuden suunnittelussa organisaatiot joutuvat toimimaan rajoitetun rationaalisuuden ja puutteellisen tiedon ja osaamisen varassa (Virtanen \& Stenvall 2014, 185). Ligthart, Keränen \& Minshall $(2018,4)$ toteavat tutkimuksessaan, että organisaatioilla on selkeä tahto innovatiivisuuteen ja verkostoitumiseen, mutta ei riittävästi keinoja tai osaamista niiden toteuttamiseen. Julkisen sektorin digihankkeissa on tällä hetkellä nähtävissä sama haaste. Digitalisaatio mahdollistaisi toteutuessaan horisontaalisen verkostoituneen ekosysteemimäisen toiminnan, mutta haasteena on tietojärjestelmien kankeus ja yhteensopimattomuus, verkostomaisen joustavan toiminnan johtamisen puuttuminen, poliittisen järjestelmän luoma epävarmuus digitalisaatioon liittyvien hankkeiden jatkuvuudesta sekä lainsäädännöstä juontuva kykenemättömyys yhtenäisen digitaalisen tiedon hyödynnettävyydestä (Gartner 2017; Virtanen \& Stenvall 2019, 53-54). Onkin todettava, että muutokset, joita digitalisaatioon liittyen on tähän mennessä pystytty toteuttamaan, ovat olleet yksittäisiä ja vähitellen tapahtuvia, eikä näin ollen voi vielä puhua julkisen hallinnon digitaalisesta transformaatiosta sen todellisessa merkityksessä.

\section{JULKISEN HALLINNON JA JOHTAMISEN PIRULLISTEN ONGELMIEN SELÄTTÄMINEN DIGITALISAATIOSSA JA DIGITAALISESSA TRANSFORMAATIOSSA}

Vaikka digitalisaation ja teknologisen kehityksen vaikutukset julkiseen hallintoon nähdään osin ristiriitaisina, näyttää julkisen hallinnon tahtotilana olevan selkeästi kautta linjan digitalisaation edistäminen ja sen tuomien mahdollisuuksien yhä laajempi hyödyntäminen ja käyttöönotto. Esimerkiksi Ikonen $(2015,50)$ toteaa digitalisaation olevan julkiselle hallinnolle välttämätön suunta, joka muuttaa johtamisen ja hallinnon prosesseja ja käytäntöjä. Tarkastelun perusteella todellinen digitaalinen transformaatio julkisessa hallinnossa odottaa vielä itseään, ja olisi syytä pysähtyä miettimään, millä keinoilla sen on mahdollista toteutua.

Albert Einstein on todennut: "Nykyisiä ongelmia on mahdotonta ratkaista samalla ajattelulla, jotka ne on aiheuttanut". Tämä sanonta pätee myös digitalisaatioon, ja kuvastaa samalla myös niitä haasteita, joita julkisessa hallinnossa digitaalisen transformaation edessä kohdataan. Julkisen hallinnon moninaisuuteen, kerroksittaisuuteen ja kompleksisuuteen liittyvät digitalisaation haasteet voikin nähdä julkisen organisaation kohtaamina vaikeasti tulkittavina, ennakoimattomina ja pirstaleisina pirullisina ongelmina, joiden ratkaiseminen perinteisillä toiminta- ja johtamismalleilla on vaikeaa tai jopa mahdotonta (Holtel 2016, 172-172; Laitinen ym. 2015, 56; Vartiainen, Ollila, Raisio \& Lindell 2013, 11-14, 31, 75-76). Digitalisaatioon liittyvät pirulliset ongelmat johtuvat paitsi hallinnon kompleksisuudesta, myös digitalisaatiosta itsestään ja sen moniulotteisesta, ennakoimattomasta ja alati muuttuvasta luonteesta. Seuraavaksi tarkastellaan muutamaa keskeisintä julkisen hallinnon digitalisaatioon liittyvää pirullista ongelmaa.

\section{Kompleksisuus julkisessa hallinnossa}

Sotaraudan $(1996,15,51,82)$ mukaan organisaation on moninaisuuden ja dynaamisuuden lisääntyessä kyettävä siirtymään stabiiliuteen pyrkivästä byrokraattisesta epävarmuuden hallinnasta epäselvyyksien hallintaan. Tämä merkitsee hänen mukaansa myös sitä, että muuttuvissa ja epävakaissa oloissa julkisen organisaation toiminnan ja hallinnan tulee itsensäkin olla moninaista, dynaamista ja jopa kompleksista. Nämä Sotaraudan 90-luvulla esittämät ajatukset pätevät hyvin myös digitaalisen transformaation kohdalla. Julkisen hallinnon ominaispiirteet ja perinteet haastavat digitaalisen transformaation toteutumisen, huolimatta siitä, että uuden julkisen hallinnan malli monella tavalla mahdollistaakin digitalisaation edellyttämää verkostomaisuutta, innovatiivisuutta ja dynaamisuutta. 
Aghina, De Smet ja Weerda (2015) Mc Kinseyltä esittävät näkemyksen, että hallinnon vakaus (stability) ja ketteryys (agility) eivät ole toisiaan poissulkevia, vaan ennemminkin toisiaan tukevia asioita. Heidän mukaansa organisaation tulee kyetä tulkitsemaan erilaisia ja eritasoisia toiminnallisia kysymyksiä, joista osa vaatii hitaampaa, perinteisempää toimintaa, ja osa puolestaan edellyttää nopeaa ja ketterää reagointia. Oikeanlainen, oikeisiin asioihin keskittyvä vakaus luo siten edellytyksiä dynaamisuudelle ja ketteryydelle.

Digitaalinen transformaatio vaatii julkisessa hallinnossa tietyn jähmeyden, vakauden, hyväksymistä mutta edellyttää myös samanaikaisesti ketterää ja kokeilevaa toimintaa. Hallinnollisia prosesseja on kyettävä analysoimaan ja arvioimaan kriittisesti, ja löytää tasapaino vakauden ja ketteryyden välille. Tarvitaan organisaatioiden kokonaisprosessien, strategioiden ja erityisesti johtamisen muuttamista siten, että digitalisoituminen muodostuu todelliseksi digitaaliseksi transformaatioksi. Olisi myös pystyttävä tarkemmin hahmottamaan, millaista julkista hallintoa tavoitellaan, tai mitä ei tavoitella, ja tehdä ratkaisuja tämän perusteella.

\section{Digitalisaation pirullinen luonne}

Digitalisaation mahdollistamien ja sitä toisaalta edellyttävien muutosten ja niiden vaikutusten ennakointi on mahdotonta, ja tulevaisuuden suunnittelussa organisaatiot joutuvat toimimaan rajoitetun rationaalisuuden ja puutteellisen tiedon ja osaamisen varassa (Virtanen \& Stenvall 2014, 185). Scott Brinker (2013) selittää julkisen hallinnon digikehitystä Martecin lain mukaan, ja toteaa haasteena olevan, että käytettävissä oleva teknologia muuttuu eksponentiaalisesti, mutta organisaatiot logaritmisesti. Tekoälyn käyttöönottoa tutkinut Stefan Holtel $(2016,174)$ näkee pirullisuuden siinä, että organisaatiot eivät tunnista digitalisaation ja teknologisen kehityksen todellista luonnetta ja merkitystä; sen sijaan se nähdään perinteisenä muutoksena, johon pyritään vastaamaan perinteisin muutosjohtamisen ja ongelmanratkaisukeinoin. Holtel (2016, 174, 176 korostaa, että tämän tyyppinen muutos edellyttää kokeilemisen, suunnittelun ja oppimisen yhdistämistä päätöksentekoon; organisaation täytyy pystyä ensin ymmärtämään, mistä esimerkiksi tekoälyssä on kyse, ja millä tavalla sitä voidaan hyödyntää organisaation toiminnassa ja prosesseissa, ja vasta sen jälkeen voidaan miettiä, miten tekoäly kyseisessä organisaatiossa otetaan käyttöön.

Myös julkisen hallinnon tulisi kyetä samanlaiseen toimintaan digitaalisen transformaation edessä; hakemaan parempaa ymmärrystä digitalisaatiosta ilmiönä, pohtimaan sen käyttökelpoisuutta organisaatioissa ja kokeilemaan joustavammin ja nopeammin erilaisia innovatiivisia toimintoja. Tätä haastaa kuitenkin se, että julkisessa hallinnossa päätöksenteko on edelleen hidasta perustuen lainsäädäntöön ja organisaatiokeskeiseen uudistumiseen.

Digitalisaation eteneminen edellyttäisi organisaatioilta selkeästi nopeampaa reagointikykyä muuttuviin tilanteisiin ja teknologisten innovaatioiden tuomiin mahdollisuuksiin. Julkiseen hallintoon kuuluva toimintavarmuuden ja -kattavuuden sekä tasapuolisuuden tavoittelu johtaa riskien pelkäämiseen ja liikaan varovaisuuteen kehittämistyössä, eikä tue myöskään digitaalista transformaatiota. Julkisissakin organisaatioissa olisi kyettävä ennakkoluulottomampaan, kokeilevaan toiminnan kehittämiseen, jossa hyväksyttäisiin toiminnan mahdollisesta epäonnistumisesta tai puutteellisesta toteutuksesta aiheutuvat riskit.

\section{Digitalisaatio julkisen hallinnon renkinä vai isäntänä?}

Holtel $(2016,176)$ korostaa digitalisaatiosta aiheutuvien pirullisten ongelmien ratkaisemisessa organisaatiokontekstin ja organisaation valitsemien teknologisten ratkaisujen yhteyttä. Organisaation täytyisi kyetä määrittelemään, millainen teknologia on sen toiminnalle hyödyllistä ja käyttökelpoista, sekä näkemään digitaalisten ratkaisujen, teknologian tai tekoälyn käyttöönoton vaikutukset organisaation kaikissa toiminnoissa ja organisaatiokulttuurissa. Jotta digitaalinen transformaatio olisi hallittua, suunniteltua ja tarkoituksenmukaista, tulee sen olla digitalisaation kaltaisen ilmiön toteuttamisessa "renki" eikä "isäntä", joka asettaa kehitykselle ja muutokselle reunaehtoja tai "sanelee" mihin suuntaan julkinen hallinto tulee kehittymään.

Jos uudistuksia ja kehittämistyötä lähdetään viemään läpi teknologia edellä, on vaarana, että 
joudutaan tilanteeseen, jossa organisaatioiden käyttöön hankitut ohjelmistot, robotit tai tekoäly määrittelevät, millaista palvelua organisaatio niiden avulla pystyy tuottamaan, tai miten organisaation sisäiset toiminnot kyetään hoitamaan. Myöskään yksityisellä sektorilla käyttöönotetut palvelukonseptit, tekniset innovaatiot tai digitaaliset sovellukset eivät välttämättä suoraan toimi julkisella puolella, eivätkä ole sellaisenaan suoraan siirrettävissä julkiseen hallinnon tai julkisten palvelujen käyttöön.

Dörner ja Edelman (2015) esittävät, että digitalisaation seurauksia ja merkitystä ei vielä riittävän hyvin tunnisteta organisaatioissa. Vaikka digitalisaatio nykyisin tuntuukin olevan "kaikkialla", olisi silti pystyttävä tunnistamaan ja kriittisesti arvioimaan myös sitä, onko teknologia ratkaistu "kaikkeen" julkisessa hallinnossa tai palveluissakaan. Digitalisaatio ei saa olla toiminnan kehittämisen päämäärä, vaan väline. Pelkkä digitaalisten ratkaisujen käyttöönotto ei sinällään auta organisaatiota kohti onnistunutta digitaalista transformaatiota. Tällä hetkellä Suomessa julkisia palveluita onkin digitalisoitu vielä varovasti, ja uusien palvelumuotojen rinnalle on nähty järkeväksi jättää myös esimerkiksi perinteinen asiakaspalvelu. Dörnerin ja Edelmanin lisäksi myös Westerman ym. (2014, 34, 42-43) pitävät digitalisaatiossa tärkeänä palveluiden kehittämistä perinteisiä ja uusia digitaalisia innovaatioita yhdistämällä. Heidän mukaansa monikanavainen ja -muotoinen palvelukokonaisuus tukee onnistunutta asiakaskokemusta myös digitaalisessa maailmassa.

\section{Tavoitteeksi pehmeä strategia?}

Digitaalisen transformaation eteneminen edellyttää, että organisaation kaikilla tasoilla ja kaikilla toimijoilla (johto, esimiehet, työntekijät) on digitalisaation tahtotila tiedossa ja omaksuttuna. Useiden tutkimusten (esim. Berman 2012, 16; 22; Westerman ym. 2014, 100-107) perusteella onnistunut digitaalinen transformaatio lähtee organisaation ylimmästä johdosta ja organisaation strategiasta. Tämä tarkoittaa sitä, että organisaation on laadittava digitalisaatiota koskeva strategia osaksi organisaation kokonaisstrategiaa, ja luotava visio siitä, millainen digitaalinen organisaatio halutaan tulevaisuudessa olla.
Julkisten organisaatioiden toiminnan ja muutosten strateginen suunnittelu on tullut teknologisen kehityksen, yhteiskunnallisten muutosten ja organisaatioiden toimintaympäristön epävakauden ja dynaamisuuden vuoksi yhä haastavammaksi. Aiempiin hallinnon malleihin kuuluneet vuositasolle tai pidemmällekin ajalle laaditut strategiat eivät ole enää toimivia, ja julkistenkin organisaatioiden toiminnan suunnitteluun on kyettävä lisäämään ketteryyttä, joustavuutta ja sopeutumiskykyä muuttuviin tilanteisiin (Hesse 2018, 1858; Juuti \& Luoma 2019, 279-279; Neubauer, Tarling \& Wade 2017, 15). Mitä pidemmälle ajalle julkisia toimintoja suunnitellaan, sen suurempi riski niillä on nopeasti muuttuvassa toimintaympäristössä epäonnistua (Murphy ym. 2017, 695).

Sotaraudan $(1996,21,32,234)$ tutkimuksessaan käyttämä termi pehmeä strategia sisältää myös tulevaisuuden julkisen hallinnon strategiatyöhön sopivia elementtejä. Sotaraudan mukaan kimmoisan ja reagointikykyisen (=pehmeän) strategian avulla organisaatio kykenee sopeutumaan dynaamisiin olosuhteisiin ja vastaamaan yhä moninaisemmiksi muodostuviin ongelmiin. Julkisen organisaation strategialta ja erityisesti digistrategialta edellytetään pehmeyttä; reagoivuutta ja muuntautumiskykyisyyttä sekä tulevaan teknologiseen ja digitaaliseen kehitykseen ketterästi sopeutumista (Saari 2016, 237-238; Sotarauta 1996, 233-237, 284; Youssef \& Luthans 2007, 778). Pehmeän strategian ja vision laadinnassa, sekä niiden pohjalta tehtävien kehittämisja uudistustoimenpiteiden toteuttamisessa keskeisenä tekijänä on myös asiakas (Westerman ym. 2014, 34-35, 45). Onnistunut pehmeä strategia pohjautuu paitsi organisaation, myös asiakkaiden, niin sisäisten kuin ulkoistenkin, tarpeisiin.

\section{Huomio johtamiseen}

Haasteena tämän ajan johtamisen määrittelyssä on digitalisaation muutosnopeus, moniulotteisuus sekä epätietoisuus siitä, millaiseksi organisaatiot tulevat muotoutumaan digitalisaation myötä. Aiemmissa tutkimuksissa (esim. Matt, Hess \& Benlian 2015, 341; Sow \& Aborbie 2018, 140) on yksimielisesti todettu oikeanlaisen johtamisen (leadership) olevan avainasemassa or- 
ganisaation digitaalisessa transformaatiossa. Myös Kane ym. (2015) toteavat digitalisaation lähtevän johdosta käsin ja Ilmarinen ja Koskela $(2015,229)$ sanovat digitalisaation olevan ennen kaikkea johtamiskysymys.

Digitaalinen transformaatio on uudistumisen johtamista (Ilmarinen ja Koskela 2015, 229) ja epävarmuuden johtamista (Ruokonen (2015, 174), mutta ennen kaikkea siinä on kyse muutoksen johtamisesta (Hearsum 2015, 227; Sow \& Aborbie 2018, 142-143). Larjovuoren ym. (2016, 1142) sekä Sown ja Aborbien (2018, 142-143) mukaan digitalisaatiossa on kyse samalla sekä muutosjohtamisesta koskien digitaalista transformaatiota että myöskin johtamisen käytäntöjen muuttumisesta itse digitaalisiksi. Tekoäly, virtuaaliset työvälineet, automatiikka ja muut teknologiset innovaatiot vaativat johtajalta riittävää teknologista osaamista, jotta hän kykenee toimeenpanemaan ja edistämään digitalisaatiota tukevia muutoksia sekä käyttämään uusia innovaatioita hyödykseen jokapäiväisessä työssään (Kane ym. 2015; Sow \& Aborbie 2018, 146).

Johtajalta edellytetään uudenlaisia kyvykkyyksiä, joiden avulla toteuttaa organisaation digistrategiaa ja johtaa organisaatiota kohti digimurrosta: organisaation dynaamisten kyvykkyyksien tunnistamista ja tukemista, sosiaalista kyvykkyyttä, laajempaa yhteistoiminnallisuutta, verkostoitumista ja nopeaa strategista reagointikykyä muuttuviin tilanteisiin. Johtajalta odotettavissa kyvykkyyksissä korostuvat Demirkanin, Spohrerin \& Welserin $(2016,14-17)$ mukaan $\mathrm{mm}$. joustavuus, innovatiivisuus ja luovuus, joiden avulla johtaja kykenee myös sietämään digitalisaation mukanaan tuomaa epävarmuutta ja häiriötä organisaation toiminnassa. Neubauer ym. $(2017,3,5)$ nostavat digitaalisen ajan johtamisen määrittelyssään esiin käsitteen ketterä johtaja, jonka tärkeimpinä ominaisuuksina näkevät ketteryyden ohella sopeutumiskyvyn, sitoutuneisuuden, visionäärisyyden ja nöyryyden. Toisaalta julkiseen johtamiseen kohdistuu julkisen hallinnon luonteen vuoksi odotuksia myös stabiiliudesta, lainmukaisuudesta ja muodollisuudesta, joten digitaalisen johtajan on työssään kyettävä tasapainottelemaan näiden ristiriitaisuuksien välillä (Murphy ym. 2017, 692-693). Julkisessa hallinnossa tulisikin tarkastella johtamiseen liittyviä kysymyksiä kokonaisvaltaisemmin, jotta löydettäisiin keinoja yhdistää teknolo- giset mahdollisuudet ja ihmisten, sekä johtajien että johdettavien, kyvyt parhaalla mahdollisella tavalla.

\section{YHTEENVETO}

Julkinen hallinto elää jatkuvassa kehämäisessä muutoksessa ja dynaamisessa kehittämisprosessissa, jossa ongelmien ratkaisut aikaansaavat uusia yhä moninaisempia haasteita toimintaympäristön muuttuessa. Viime aikoina muutosten keskeisenä lähteenä on ollut digitalisaatio ja sen monitahoiset vaikutukset työhön, yhteiskuntaan, organisaatioiden toimintaan ja asiakkaiden tarpeisiin. Digitalisaatio tulee muokkaamaan julkisen hallinnon toimintaa ja rakenteita sekä julkisen johtamisen sisältöä ja käytäntöjä lähivuosien ja vuosikymmenien aikana, vaikka vielä ei täydellisestä digitaalisesta transformaatiosta voidakaan ongelmitta puhua. Tämän artikkelin tarkoituksena oli tarkastella julkisen hallinnon haasteita ja mahdollisuuksia digitaalisen transformaation läpiviemisessä sekä pohtia, miten digitalisaatioon liittyviä haasteita voitaisiin hallita. Tavoitteena oli löytää vastaukset alussa asetettuihin tutkimuskysymyksiin: 1) millaisia haasteita ja jopa pirullisiksi muodostuvia ongelmia digitaalinen transformaatio aikaansaa julkisessa hallinnossa, ja 2) miten nämä haasteet ja ongelmat voitaisiin ratkaista, jotta digitaalinen transformaatio toteutuisi hallitusti. Julkisen hallinnon haasteita ja mahdollisuuksia digitaaliseen transformaatioon liittyen kuvattu taulukossa 1.

Julkisen hallinnon digitaalisen transformaation eteneminen edellyttää haasteiden tunnistamista ja niihin sopeutumista. Julkisen hallinnon, kuten digitalisaationkin, luonteen vuoksi kaikkia haasteeksi tunnistettuja tilanteita ei pystytä poistamaan, mutta ne voidaan kääntää oikeilla toimilla myös mahdollisuuksiksi digitaalisen transformaation toteutumiseksi. Tämä edellyttää julkiselta hallinnolta muutoksia niin strategiatyössä, johtamisessa kuin tulevaisuuden osaamistarpeiden arvioinnissa.

Mitä laajempia yksiköitä tai kokonaisuuksia muutosten halutaan koskettavan, sitä hitaampaa ja työläämpää niiden aikaansaaminen on tulevaisuudessakin. Uudistumista ja kehittymistä ei voi tehdä sattumanvaraisesti ja lyhytjänteisesti digimurroksenkaan aikana. Jotta teknologiaa ja sen kehittymistä voitaisiin hallita julkisessa 
Taulukko 1. Julkisen hallinnon haasteet ja mahdollisuudet digitaalisessa transformaatiossa

\begin{tabular}{|c|c|}
\hline Haaste & Mahdollisuus \\
\hline $\begin{array}{l}\text { Julkisen hallinnon kompleksisuus } \\
\text { - hallinnon pirstaleisuus } \\
\text { - konsensushakuisuus } \\
\text { - lainsäädännön kankeus } \\
\text { - tietojärjestelmien yhteensopimattomuus } \\
\text { - yhdenvertaisuuden tavoittelu } \\
\text { - jatkuvuuden puute } \\
\text { - stabiiliuden ja turvallisuuden tavoittelu }\end{array}$ & $\begin{array}{l}\text { Kompleksisuuden hyväksyminen ja } \\
\text { hyödyntäminen } \\
\text { - kehityksen jatkuvuuden varmistaminen } \\
\text { - liiallisesta yhdenmukaisuuden tavoittelusta } \\
\text { luopuminen } \\
\text { - lainsäädännön kehittäminen } \\
\text { - tasapaino stabiiliuden ja ketteryyden välille } \\
\text { - verkostomaisuuden lisääminen } \\
\text { - asiakkaan osallistaminen ja asiakastiedon } \\
\text { - tietojärjestelmien ja tiedon hyödynnettävyyden } \\
\text { parantaminen }\end{array}$ \\
\hline $\begin{array}{l}\text { Digitalisaation pirullinen luonne } \\
\text { - teknologisen kehityksen eksponentiaalisuus } \\
\text { - muutosten ennakoinnin vaikeus } \\
\text { - ymmärryksen ja osaamisen puute }\end{array}$ & $\begin{array}{l}\text { Ilmiön moninaisuuden hyväksyminen } \\
\text { • riittävän ymmärryksen ja osaamisen lisääminen } \\
\text { • joustavuuden ja kokeilujen merkityksen } \\
\text { korostaminen }\end{array}$ \\
\hline $\begin{array}{l}\text { Digitalisaatio - isäntä vai renki? } \\
\text { - uudistaminen teknologian ehdoilla } \\
\text { - yksityisen sektorin konseptien } \\
\text { - soveltumattomuus julkiselle sektorille } \\
\text { - tavoitetilan epäselvyys }\end{array}$ & $\begin{array}{l}\text { Halutun tavoitetilan määrittely } \\
\text { - digitalisaation näkeminen toiminnan } \\
\text { kehittämisen välineenä } \\
\text { - monimuotoiset palvelukokonaisuudet }\end{array}$ \\
\hline $\begin{array}{l}\text { Strategiset haasteet } \\
\text { - } \quad \text { tulevaisuuden epävarmuus ja muutosten } \\
\text { nopeus } \\
\text { - } \quad \text { suunnittelu jäykkyys } \\
\text { - perinteisen strategian epäonnistumisen vaara }\end{array}$ & $\begin{array}{l}\text { Pehmeän strategian hyödyntäminen } \\
\text { - joustavuus ja reagointikykyisyys } \\
\text { - hallittu riskien ottaminen } \\
\text { - dynaamisten kyvykkyyksien hyödyntäminen ja } \\
\text { - kehittäminen } \\
\text { digistrategian laatiminen }\end{array}$ \\
\hline $\begin{array}{l}\text { Johtamiseen kohdistuvat muutostarpeet } \\
\text { • } \quad \text { riittämätön ymmärrys digitalisaatiosta ja sen } \\
\text { vaikutuksista } \\
\text { • digitalisaation ja digitaalisen transformaation } \\
\text { edellyttämän osaamisen puute }\end{array}$ & $\begin{array}{l}\text { Johtamisen merkityksen tunnistaminen } \\
\text { - tarvittavien kyvykkyyksien ja osaamisen } \\
\text { tunnistaminen } \\
\text { - johtaja osallistajana ja muutoksen eteenpäin } \\
\text { viejänä } \\
\text { - digitaalisuuden hyödyntäminen johtamisen } \\
\text { käytännöissä } \\
\text { - avoimen organisaatiokulttuurin luominen }\end{array}$ \\
\hline
\end{tabular}

toiminnassa paremmin, tarvitaan suunnitelmia ja päätöksiä siitä, mitä teknisiä ja digitaalisia innovaatioita todella halutaan, mitä on tarpeen ja mitä mahdollista lähteä toteuttamaan. Digitaalisen transformaation toteutuminen edellyttää julkiselta hallinnolta selkeän tulevaisuuden tahtotilan määrittelyä, laaja-alaista ja ennakkoluulotonta kykyä uudistua, sekä oman asemansa ja roolin uudelleenmäärittelyä. On myös pystyttävä tarkemmin hahmottamaan, millaista julkista hallintoa maassamme tavoitellaan, tai mitä ei tavoitella, ja tehdä ratkaisuja digitaalisten innovaatioiden hyödyntämisestä ja soveltamista hal- litusti ja suunnitellusti tämän perusteella. Jos tässä ei onnistuta, on vaarana, että julkinen hallinto ei kykene vastaamaan yhteiskunnan, poliittisten päättäjien eikä myöskään asiakkaiden odotuksiin ja tarpeisiin.

Digitaalista julkista organisaatiota ei voi kaikin osin johtaa samoin kuin byrokraattista linjaorganisaatiota. Haasteena on johtamisen ottaminen kokonaisvaltaisemmin haltuun, ja sen selkiyttäminen mikä digitaalista muutosta ohjaa ja mikä on organisaation oma tahtotila sen johtamisessa ja sen avulla. Digitalisaatio on julkiselle organisaatiolle ennen kaikkea strateginen haaste. 
Osana organisaation strategiaa digitalisaatio on sekä päämäärä että keino strategisten tavoitteiden saavuttamiseksi ja organisaation dynaamisen kyvykkyyden lisäämiseksi. Pehmeän, reagointikykyisen strategian avulla organisaatio kykenee vahvistamaan dynaamisia kyvykkyyksiään selvitä toimintaympäristön kompleksisuuden ja ennakoimattomuuden lisääntymisestä.

Vaikka täydellinen digitaalinen transformaatio vielä näyttääkin odottavan itseään julkisella sektorilla, saattaa koko maailmaa kohdannut korona-epidemia vauhdittaa muutoksen toteutumista. Epidemia on pakottanut julkisen sektorin toimijat ottamaan ison askeleen, ainakin väliaikaisesti, digitaalisen transformaation suuntaan. Julkisten palvelujen toiminnan turvaamiseksi on haettu ratkaisuja digitaalisuudesta, esimerkiksi sähköisestä asioinnista, korvaamaan perinteisiä palvelukanavia jopa kokonaan. Esimerkiksi Kelan palvelutoimistoja ja Poliisin palvelupisteitä samoin kuin kuntien palveluita on suljettu

\section{LÄHTEET}

Ailisto, Heikki, Anssi Neuvonen, Henrik Nyman, Marco Halen \& Timo Seppälä (2019). Tekoälyn kokonaiskuva ja kansallinen osaamiskartoitus - loppuraportti. Valtioneuvoston selvitys- ja tutkimustoiminnan julkaisusarja 4/2019.

Alasoini, Tuomo. 2015: Digitalisaatio muuttaa työtä - millaista työelämää uudistavaa innovaatiopolitiikkaa tarvitaan? Työpoliittinen aikakauskirja 2/2015, 26-37. Työ- ja elinkeinoministeriö.

Aghina, Wouter, Aaron De Smet \& Kirsten Weerda (2015). Agility: It rhymes with stability. Haettu sivulta https://www.mckinsey.com/business-functions/organization/our-insights/agility-it-rhymes-with-stability, 30.8.2019.

Berman, Saul J. (2012). Digital transformation: opportunities to create new business models. Strategy \& Leadership 40(2), 16-24.

Bilefield, James (2016). Digital transformation: The three steps to success. Haettu sivulta https:// www.mckinsey.com/business-functions/digital-mckinsey/our-insights/digital-transformation-the-three-steps-to-success, 7.8.2019.

Business Dictionary. Haettu sivulta http://www. businessdictionary.com/, 23.9.2019.

Collin, Jari (2015). Digitalization and dualistic IT. Teoksessa Collin, Jari, Kari Hiekkanen, Janne J. Korhonen, Marco Halén, Timo Itälä \& Mika Helenius (Eds.), IT leadership in transition. The impact of digitalization on Finnish organizations ja asiakkaita on ohjattu entistä vahvemmin sähköisiin palveluihin ja sähköiseen asiointiin (Kela 2020; Kuntaliitto 2020; Poliisi 2020). Koulujen lähiopetus on keskeytetty ja opetus toteutuu pääosin etäopetuksena digitaalisilla välineillä, ja terveydenhuollossa on lisätty etävastaanottojen saatavuutta (STT, 2020; OAJ 2020) Myös etätyötä tekevien määrä julkisissa organisaatioissa on kasvanut, ja tähän saakka paperilla tehtyä työtä on muutettu sähköiseen muotoon (Kela 2020, YLE, 2020) Jää nähtäväksi, mitä vaikutuksia tällä on digitaalisten palveluiden ja niitä ohjaavan lainsäädännön kehittämiseen tai millaisille perinteisille asiointikanaville ja -tavoille jatkossa on tarvetta korona-epidemian laannuttua. Koronaepidemian myötä ollaan jopa lähempänä sitä, että digitaalisten palvelujen käyttäminen tulee pakolliseksi. Poikkeustilanteella saattaa olla merkittävä vaikutus digitaalisen transformaation etenemiseen.

(s. 29-34). Aalto University publications series. Helsinki: Unigrafia Oy.

Eisenhardt, Kathleen M. \& Jeffrey A. Martin (2000). Dynamic capabilities: what are they? Strategic Management Journal 21(10/11), 1107-1121.

Dan, Sorin (2019). Is technology really changing the public sector? Haettu sivulta https://www.univaasa.fi/fi/blogs/expert/inno/is_technology_really_changing_the_public_sector/, 25.8.2019.

Demirkan, Haluk, James C. Spohrer \& Jeffrey J. Welser (2016). Digital Innovation and Strategic Transformation. IT Professional 18(6), 14-18.

Drath, Rainer \& Alexander Horch (2014). Industrie 4.0: Hit or Hype? IEEE Industrial Electronics Magazine 8(2), 56-58.

Dörner, Karin \& David Edelman (2015). What "digital" really means. Haettu sivulta https://www. mckinsey.com/industries/high-tech/our-insights/what-digital-really-means, 11.8.2019.

Ford, Martin (2015). Robottien kukoistus. Turku: Kustannusosakeyhtiö Sammakko.

Gartner (2017). Digitalisaation kärkihankkeiden arviointi. Haettu sivulta https://vm.fi/documents/10623/6305487/Digitalisaation+k\% C3\%A4rkihankkeiden+arviointi/23ec25eda2ca-4ec4-b0a1-adaa90e5732b/Digitalisaation +k\%C3\%A4rkihankkeiden+arviointi.pdf, 15.9.2019. 
Gartner (2018). Gartner identifies six barriers to becoming a digital business. Haettu sivulta https:// www.gartner.com/en/newsroom/press-releases/2018-07-25-gartner-identifies-six-barrierto-becoming-a-digital-business, 10.8.2019.

Gidlund Katarina L. (2015). Makers and shapers or users and choosers. Esitetty 14th IFIP WG 8.5 International Conference on Electronic Government 30.8-2.9.2015. Thessaloniki, Kreikka.

Haveri, Arto \& Jenni Airaksinen (2012). Uudelleenskaalausta kunta- ja palvelurakenteissa. Teoksessa Anttonen, Anneli, Arto Haveri, Juhani Lehto \& Hannele Palukka (toim.), Julkisen ja yksityisen rajalla. Julkisen palvelun muutos (s. 305-334). Tampere: Tampere University Press.

Hearsum, Steve (2015). How to develop digital leadership capability. Strategic HR Review 14(5), 206-210.

Holtel, Stefan (2016). Artificial intelligence creates a wicked problem for the enterprise. Procedia Computer Science 99, 171-180.

Hämäläinen, Virpi, Hanna Maula \& Kimmo Suominen (2016). Digiajan strategia. Helsinki: Talentum Media Oy.

Ikonen, Raimo (2015). Julkinen johtaminen - ansiokas menneisyys ja loistava tulevaisuus. Teoksessa Ahonen, Guy, Päivi Husman, Raimo Ikonen, Pauli Juuti, Arto Koho, Sari Käpykangas, Marjukka Laine, Eeva Larjomaa, Tiina Saarelma-Thiel, Eveliina Saari \& Marjo Wallin (toim.), Julkista johtamista jalostamassa (s. 23-55). Keuruu: Otavan Kirjapaino.

Ilmarinen, Vesa \& Kai Koskela (2015). Digitalisaatio: yritysjohdon käsikirja. Helsinki: Talentum.

Juuti, Pauli \& Mikko Luoma (2019). Strategian luominen. Miten vastata kompleksisen ja postmodernin ajan haasteisiin? Helsinki: Kustannusosakeyhtiö Otava.

Kane, Gerald C., Doug Palmer, Anh Nguyen Phillips, David Kiron \& Natasha Buckler (2015). Strategy, not technology, drives digital transformation. Becoming a Digitally Mature Enterprise. Haettu sivulta https://sloanreview.mit.edu/ projects/strategy-drives-digital-transformation/, 1.8.2019.

Kela (2020). Ajankohtaista koronatilanteesta. Haettu sivulta https://www.kela.fi/korona, 30.3. 2020.

Kelan strategia 1.1.2020. Haettu Kelan sisäisiltä verkkosivuilta 1.11.2019.

Kenney, Martin, Petri Rouvinen \& John Zysman (2015). The digital disruption and its societal impacts. Journal of Industry 15(1), 1-4.

Kuntaliitto (2020). Koronavirus: Koottuja ohjeita ja yhteystietoja. Haettu sivulta https://www.kuntaliitto.fi/koronavirus, 29.3.2020.

Laitinen, Ilpo, Inga Nyholm, Jari Stenvall \& Jari Kaivo-oja (2015). The complex relational dynamics in public sector reforms. European Integration Studies vol. 9 (2015), 53-59.

Laki digitaalisten palvelujen tarjoamisesta, 1.4.2019/306.

Laki julkisen hallinnon tiedonhallinnasta, 9.8. 2019/906.

Ligthart, Ruusa, Keränen, Krista \& Tim Minshall (2018). An initial framework for open service innovation adopting digital co-creation. Esitetty ISPIM Innovation Conference 17.-20.6.2018. Tukholma, Ruotsi.

Larjovuori, Riitta-Liisa, Laura Bordi, Jaana-Piia Mäkiniemi \& Kirsi Heikkilä-Tammi (2016). The role of leadership and employee well-being in organizational digitalization. Esitetty 26th Annual RESER Conference. Napoli, Italia.

Lähdesmäki, Kirsi (2011). New Public Management julkisjohtamisen uudistajana - yhä kestosuosikki reformeissa? Teoksessa Hyyryläinen, Esa \& Olli-Pekka Viinamäki (toim.), Julkinen hallinto ja julkinen johtaminen (s. 75-87). Acta Wasaensia no 238.

Matt, Christian, Thomas Hess \& Alexander Benlian (2015). Digital transformation strategies. Business \& Information Systems Engineering. 57(5), 339-343.

Maula, Hanna (2016). Perinteinen strategiatyö on aikansa elänyt. Haettu sivulta https://www. talouselama.fi/uutiset/perinteinen-strategiatyo-on-aikansa-elanyt/d31b4c6e-1eea-3102a389-ceelf8866925, 15.8.2019.

Murphy, Joanne, Mary Lee Rhodes, Jack Meek \& David Denyer (2017). Managing the Entanglement: Complexity Leadership in Public Sector Systems. Public Administration Review 77(5), 692-704.

Neubauer, Rainer, Andrew Tarling \& Michael Wade (2017). Redefining leadership for a digital age. Haettu sivulta https://www.enricsegarra. com/wp-content/uploads/REDEFININGLEADERSHIP-FOR-A-DIGITAL-AGE-IMD. pdf, 15.8.2019.

Nordin, Patrik \& Jarno Parviainen (2018). Viranomaistehtävien synergioista lähtevä hallinnon organisoiminen - Kokonaisetu ja asiakaslähtöiset palvelut kolmella eri hallinnonalalla. Hallinnon Tutkimus 37(1), 37-52.

Nyholm, Inga, Jenni Airaksinen \& Arto Haveri (2016). Julkisen hallinnon uudistamista säätelevät toimintaympäristömuutokset ja kehittämisimpulssit. Teoksessa Nyholm, Inga, Jari 
Stenvall, Jenni Airaksinen, Elias Pekkola, Arto Haveri, Klaus af Ursin \& Seppo Tiihonen (toim.), Julkinen hallinto Suomessa (s. 197-236). Helsinki: Tietosanoma Oy.

OAJ (2020). Koulut ja oppilaitokset siirtyvät kuukaudeksi etäopetukseen - palkka maksetaan normaalisti. Haettu sivulta https://www.oaj.fi/ ajankohtaista/uutiset-ja-tiedotteet/2020/koronavirus-etaopetus/, 29.3.2020.

Osborne, Stephen (2006). The New Public Governance. Public Management Review 8(3), 377-387.

Pablo, Amy L., Trish Reay, James R. Dewald \& Ann L. Casebeer (2007). Identifying, Enabling and Managing Dynamic Capabilities in the Public Sector. Journal of Management Studies 44(5), 687-708.

Pekkola, Elias, Arto Haveri \& Klaus af Ursin (2016). Julkisen hallinnon tehtävä, olemus, päämäärä ja arvot. Teoksessa Nyholm, Inga, Jari Stenvall, Jenni Airaksinen, Elias Pekkola, Arto Haveri, Klaus af Ursin \& Seppo Tiihonen (toim.), Julkinen hallinto Suomessa (s. 15-29). Helsinki: Tietosanoma Oy.

Poliisi (2020). Asiakaspalvelu. Haettu sivulta https://www.poliisi.fi/asiakaspalvelu, 30.3.2020.

Poliisin strategia 2017-2020. Haettu sivulta https:// www.poliisi.fi/strategia, 11.10.2019.

Russell, Stuart \& Peter Norvig (2003). Artificial Intelligence: A Modern Approach (2nd ed.) New Jersey: Prentice Hall.

Saari, Tiina (2016). Resilienssi työntekijän voimavarana asiantuntijatyön aikapaineiden hallinnassa. Hallinnon tutkimus 35(3), 232-243.

Siukonen, Timo \& Pekka Neittaanmäki (2019). Mitä tulisi tietää tekoälystä. Jyväskylä: Docendo Oy.

Sotarauta, Markku (1996). Kohti epäselvyyden hallintaa: pehmeä strategia 2000-luvun alun suunnittelun lähtökohtana. Acta Futura Fennica No 6. Jyväskylä: Finnpublishers.

Sow, Mouhamadou \& Solomon Aborbie (2018). Impact of leadership on digital transformation. Business and Economic Research 8(3), 139-148.

Stenvall, Jari, Ilpo Laitinen, Klaus af Ursin, Petri Virtanen \& Jari Kaivo-oja (2014). Constructing Public Services - European approach. European Integration Studies vol. 8 (2014), 22-27.

Stenvall, Jari, Klaus af Ursin, Seppo Tiihonen, Inga Nyholm \& Jenni Airaksinen (2016). Julkisen hallinnon kehitys Suomessa. Teoksessa Nyholm, Inga, Jari Stenvall, Jenni Airaksinen, Elias Pekkola, Arto Haveri, Klaus af Ursin \& Seppo Tiihonen (toim.), Julkinen hallinto Suomessa (s. 31-68). Helsinki: Tietosanoma Oy.
STT (2020). HUS siirtyy etävastaanottojen käyttöön. Haettu sivulta https://www.sttinfo.fi/tiedote/hus-siirtyy-etavastaanottojen-kayttoon?publisherId $=23980819$ \& releaseId $=69877922$, 3.4.2020.

Sydänmaanlakka, Pentti (2015). Älykäs julkinen johtaminen. Helsinki: Talentum Media Oy.

Teece, David J., Gary Pisano \& Amy Shuen (1997). Dynamic capabilities and strategic management. Strategic Management Journal 18(7), 509-533.

Teece, David J. (2018). Business models and dynamic capabilities. Long Range Planning 51(1), 40-49.

Työ- ja elinkeinoministeriö (2017). Suomen tekoälyaika. Suomi tekoälyn soveltamisen kärkimaaksi: Tavoite ja toimenpidesuositukset. Työja elinkeinoministeriön julkaisuja 41/2017.

Työ- ja elinkeinoministeriö (2018). Tekoälyajan työ. Neljä näkökulmaa talouteen, työllisyyteen, osaamiseen ja etiikkaan. Työ- ja elinkeinoministeriön julkaisuja 2018: 19.

Työ- ja elinkeinoministeriö (2019). Edelläkävijänä tekoälyaikaan. Tekoälyohjelman loppuraportti. Työ- ja elinkeinoministeriön julkaisuja 2019: 23.

Valkama, Pekka \& Ari-Veikko Anttiroiko (2011). Innovaatioperusteinen palvelutalouden muutos: verkostoitumisen ja digitalisaation vaikutukset julkisiin palveluihin. Kansantaloudellinen aikakauskirja 107(3), 256-273.

Valtiovarainministeriö (2017a). Hyvän hallinnon ja kyvykkyyksien tärkeydestä digitalisaatiossa. Valtiovarainministeriön julkaisu 4/2017.

Valtiovarainministeriö (2017b). Pilkahduksia tulevaisuuteen - digitalisaation ja robotisaation mahdollisuudet. Valtiovarainminiteriön julkaisu $10 / 2017$.

Valtiovarainministeriö (2019a). AuroraAI - kohti ihmiskeskeistä yhteiskuntaa. Kansallisen tekoälyohjelma Auroran esiselvityshankkeessa tuotettu kehittämis- ja toimeenpanosuunnitelma 2019-2023.

Valtiovarainministeriö (2019b). Digitaalinen Suomi - Yhdenvertainen kaikille. Digi arkeen - neuvottelukunnan toimintakertomus. Valtiovarainministeriön julkaisuja 2019:23.

Valtiovarainministeriö (2020). Digitalisaation edistämisen ohjelma 2020-2023. Toimintasuunnitelma 2020. Haettu sivulta https://vm.fi/ digitalisaation-edistamisen-ohjelma, 27.3.2020.

Vartiainen, Pirkko, Seija Ollila, Harri Raisio \& Juha Lindell (2013). Johtajana kaaoksen reunalla. Kuinka selviytyä pirullisista ongelmista. Helsinki: Gaudeamus Oy.

Verohallinto (2019a). Verohallinnon strategia 2019-2024. Haettu sivulta https://www.vero.fi/ 
tietoa-verohallinnosta/verohallinnon_esittely/ verohallinnon_strategia/, 11.10.2019.

Verohallinto (2019b). Virheellisten verokirjeiden syy selvitetty -asiakkaille lähetetään uudet kirjeet. Haettu sivulta https://www.vero.fi/tietoa-verohallinnosta/uutishuone/lehdist\%C3\%B6tiedotteet/2019/virheellisten-verokirjeiden-syy-selvitetty---asiakkaille-1\%C3\%A4hetet\%C3\%A4\%C3\%A4n-uudet-kirjeet/, 15.9.2019.

Westerman, George, Didier Bonnet \& Andrew McAfee (2014) Leading Digital. Turning tech- nology into business transformation. Boston: Harvard Business Review Press.

Virtanen, Petri \& Jari Stenvall (2014). Älykäs julkinen organisaatio. Helsinki: Tietosanoma Oy.

Virtanen, Petri \& Jari Stenvall (2019). Julkinen johtaminen. Helsinki: Tietosanoma Oy.

YLE (2020). Koronavirus synnytti etätyöbuumin, joka saattaa mullistaa työelämän. Haettu sivulta https://yle.fi/uutiset/3-11257808, 30.3.2020.

Youssef, Carolyn \& Fred Luthans (2007). Positive Organizational Behavior in Workplace. The impact of hope, optimism and resilience. Journal of Management 33: 5, 774-800. 